Naunyn-Schmiedebergs Arch. Pharmak. 267, 421-432 (1970)

(C) by Springer-Verlag 1970

\title{
Histamine and Histamine Methyltransferase in the Gastric Mucosa of Man, Pig, Dog and Cow
}

\author{
W. Lorenz, H. BarTH, and E. WerLw \\ Institut für Klinische Chemie und, Klinische Biochemie \\ der Universität München
}

Received April 8, 1970

\begin{abstract}
Summary. High histamine concentrations and histamine methyl transferase activity were demonstrated in the gastric mucosa of man, dog, pig and cow. Modified, methods for the determination of histamine and histamine methyltransferase were developed. Histamine was identified by its fluorescence spectrum, by thin-layer chromatography in 8 different solvent systems and by bioassay. Histamine methyltransferase from pig antral mucosa was purified, 6 -fold by ultra-centrifugation and fractional precipitation by ammonium sulfate. Its $K_{m}$ for histamine as substrate was $2.3 \times 10^{-5} \mathrm{M}$, for S-adenosylmethionine $4.3 \times 10^{-5} \mathrm{M}$, the $\mathrm{pH}$-optimum was found to be $\mathrm{pH}$ 7.4. Nicotinamide in concentrations up to $1 \times 10^{-2} \mathrm{M}$ had no effect on the activity of the enzyme.
\end{abstract}

Key-Words: Histamine - Histamine Methyltransferase - Gastric Mucosa.

In man and dog histamine is mainly inactivated by methylation at the imidazole nucleus (Schayer, 1956, 1956a). The enzyme which catalyses this reaction (Lindahl, 1958; Brown et al., 1959) was named. histamine methyltransferase (S-adenosylmethionine: histamine-N-methyltransferase E.C. 2.1.1.8) because of its high substrate specifity. Among many imidazole derivates studied, only histamine was methylated by this enzyme (Brown et al., 1959) and S-adenosylmethionine was found to be the methyl donor.

The activity of histamine methyltransferase was determined in numerous organs of rodents (Brown et al., 1959). In higher mammals the enzyme was detected in the liver of man and pig (Lindahl, 1960), in the nervous system and in glands of monkey (Axelrod et al., 1961) and in some organs of the digestive tract of cat and dog (Brown et al., 1959; Kim et al., 1969). Since histamine is assumed to be a common physiological chemostimulator of gastric secretion (Code, 1956; Lorenz and Pfleger, 1968), studies on the occurrence and distribution of histamine methyltransferase in the gastric mucosa of man and higher mammals seemed to be useful, because diamine oxidase, another important enzyme of histamine inactivation, could not be demonstrated in the gastric mucosa of man and many other mammals (Kusche et al., 1969). 


\section{Materials and Methods \\ Preparation and Purification of Histamine \\ Methyltransferase}

Human gastric tissues obtained from patients having a chronical duodenal ulcer and being treated, by a Billroth II gastrectomy, or gastric tissues from pigs, cows (slaughter-house) and dogs (laboratory animals) were rinsed with ice cold Tyrode solution immediately after the surgical treatment of the patient or the death of the animal. The mucosa was stripped off from the musoular layer, frozen by dry ice and stored in a deepfreeze at $-20^{\circ} \mathrm{C}$ for several days. Guinea-pig brains were obtained from about 30 adult male animals immediately after decapitation.

Crude extracts of histamine methyltransferase were prepared by homogenizing the frozen tissues with 2 volumes of $0.25 \mathrm{M}$ sucrose solution. The homogenate, which was proved to have a $\mathrm{pH}$ of 6.8 , was centrifuged at $2^{\circ} \mathrm{C}$ and $50000 \times \mathrm{g}$ for $30 \mathrm{~min}$ and the supernatant was used as the source of the enzyme.

As a first step of purification, these crude extracts from pig antral mucosa and guinea-pig brain were fractionated by ammonium sulfate precipitation $(45-70 \%$ saturation, as described by Brown et al., 1959). The precipitate was dissolved in $0.005 \mathrm{M}$ sodium phosphate buffer, $\mathrm{pH} 7.4$, and desalted on Sephadex G 25. The fractions containing proteins were collected, lyophilized and used for studies on the properties of histamine methyltransferase of pig antral mucosa.

Reagents. Histamine dihydrochloride purissimum, o-phthaldialdehyde purissimum p.a. (recrystallized from ligroin p.a., b.p. 50-70 ${ }^{\circ} \mathrm{C}$ ) (Fluka). Nicotinamide, methanol (Uvasol ${ }^{\circledR}$ ) (Merck, Darmstadt). Sephadex G 25 (fine) (Deutsche Pharmacia Gesellschaft). Aminoguanidine sulfate (Schuchardt). Dowex $50 \mathrm{~W}-\mathrm{X} 8, \mathrm{H}^{+}$, mesh 200-400, (Serva). S-adenosylmethionine hydrogen sulfate (Boehringer, Mannheim $^{1}$ ). Cellulose MN 300 for thinlayer chromatography (Macheray, Nagel \& Co). All aqueous solutions mentioned in this paper were prepared in twice distilled water.

\section{Determination of Histamine Methyltransferase}

Preparation of the Incubation Mixtures. Crude extracts, resp. the purified enzyme preparation were incubated in the shaking incubator IH-350 (Gallenkamp, London) at $37^{\circ} \mathrm{C}$ under air. The incubation mixtures were prepared in $30 \mathrm{ml}$ glass-stoppered Erlenmeyer flasks at $0^{\circ} \mathrm{C}$. They consisted of $1.0 \mathrm{ml}$ of $0.05 \mathrm{M}$ sodium phosphate buffer $\mathrm{pH} 7.4,1.0 \mathrm{ml}$ of $0.25 \mathrm{M}$ sucrose and $1.0 \mathrm{ml}$ of enzyme solution. The following reagents were added (final concentrations in parentheses): $0.1 \mathrm{ml}$ aminoguanidine $\left(1.0 \times 10^{-4} \mathrm{M}\right), 0.1 \mathrm{ml}$ nicotinamide $\left(1.0 \times 10^{-2} \mathrm{M}\right), 0.1 \mathrm{ml} \mathrm{MgCl}_{2}\left(5 \times 10^{-3} \mathrm{M}\right)$ and $0.5 \mathrm{ml}$ histamine $\left(0.8-1.4 \times 10^{-4} \mathrm{M}\right.$, see results). After a preincubation time of $10 \mathrm{~min}$ at $37^{\circ} \mathrm{C}$ the reaction was started by the addition of $0.2 \mathrm{ml} \mathrm{S}$-adenosylmethionine $\left(2.5 \times 10^{-4} \mathrm{M}\right)$. The final volume of the incubation mixture was $4.0 \mathrm{ml}$. All reagents except $\mathrm{MgCl}_{2}$, which was dissolved in water, were prepared in $0.05 \mathrm{M}$ sodium phosphate buffer ( $\mathrm{pH}$ 7.4).

Determination of Histamine. After an incubation time of 5-15 min (see below), the reaction was stopped by the addition of $1.0 \mathrm{ml}$ of $2 \mathrm{~N} \mathrm{HClO}_{4}$. The mixture was centrifuged at $1800 \times \mathrm{g}$ for $5 \mathrm{~min}$ and the supernatant was used for the determination of histamine by a modification of the method of Thunberg (1967). $0.6 \mathrm{ml}$ of $2 \mathrm{~N}$ $\mathrm{NaOH}$ and $10 \mathrm{ml}$ of $0.1 \mathrm{M}$ sodium phosphate buffer ( $\mathrm{pH}$ 6.5) were added to $3 \mathrm{ml}$ of the supernatant and the solution was applied to a small column of Dowex $50 \mathrm{~W}$ $\mathrm{X}-8, \mathrm{H}^{+}(0.3 \times 2 \mathrm{~cm}$, equilibrated with $0.1 \mathrm{M}$ sodium phosphate buffer, $\mathrm{pH} 6.5)$.

1 We thank Dr. M. Nelboeck from Boehringer, Mannheim, for the generous gift of S-adenosylmethionine. 
The column was in turn washed with $5.0 \mathrm{ml}$ of $0.1 \mathrm{M}$ sodium phosphate buffer pH $6.5,1.0 \mathrm{ml}$ water and $5.0 \mathrm{ml}$ of $1 \mathrm{~N} \mathrm{HCl}$, and histamine eluted, with $3.0 \mathrm{ml}$ of $4 \mathrm{~N} \mathrm{HCl}$. For the fluorometric determination of the amine, the eluate was diluted with an equal volume of water. $1.7 \mathrm{ml}$ of this solution was mixed, with $0.8 \mathrm{ml}$ of $5 \mathrm{~N} \mathrm{NaOH}$ and $0.1 \mathrm{ml}$ of o-phthaldialdehyde $(1 \% \mathrm{w} / \mathrm{v}$, dissolved in methanol).

Exactly 2 min later $0.6 \mathrm{ml}$ of $2 \mathrm{M} \mathrm{H}_{3} \mathrm{PO}_{4}$ were added and the fluorescence measured at $21^{\circ} \mathrm{C}$ in a Zeiss spectrofluorometer. The activation wavelength was $360 \mathrm{~nm}$, the fluorescence wave length was $450 \mathrm{~nm}$. The fluorescent histamine-0-phthaldialdehyde complex was stable for at least $30 \mathrm{~min}$. The fluorescence intensity was directly proportional to the histamine concentration in a range of $1-700 \mathrm{ng}$ of histamine dihydrochloride $/ \mathrm{ml}$ of the diluted eluate. The recovery of various amounts of histamine, which had been added to some reaction samples after addition of perchloric acid, was 95-100\%. The coefficient of variation (Snedecor and Cochran, 1967), calculated from 18 determinations of authentic histamine, was $5.4 \%$.

Identification of Histamine. The substance, isolated by ion-exchange chromatography, was identified as histamine by three different methods: the results of the fluorometric measurement were compared with those obtained by the biological assay of histamine on the isolated guinea-pig ileum and on the systemic blood pressure of the anesthetized cat. The activation and fluorescence spectra of the substance were compared with those of authentic histamine. After thin-layer chromatography on cellulose in 8 different solvent systems, the $R_{f}$-values of the substance isolated from the tissues were compared with those of authentic histamine. The following solvent systems were used (v/v): 1. Ethanol-ammonia (25\%) 80:20, 2. ethanoldiethylether-ammonia $(25 \%)$-water 48:60:6:12. 3. ethanol-ammonia $(25 \%)$ water 100:10:10. 4. n-butanol, saturated with $\mathrm{N}$ HCl. 5. $100 \mathrm{~g}$ phenol-30 ml water. 6. methanol-acetic acid 125: 1.25. 7. n-butanol-pyridine-water 40:40:40. 8. n-butanol-acetic acid-water 50:12.5:62.5.

Determination of Protein. High concentrations of protein were determined by the biuret method (Weichselbaum, 1946), low concentrations by the spectrophotometric measurement of the light absorption at $280 \mathrm{~nm}$ and $260 \mathrm{~nm}$ (Warburg and Christian, 1936).

Determination of Enzyme Activity. The activity of histamine methyltransferase was determined by the disappearance of histamine in the presence of S-adenosylmethionine as the methyl donor. Three reaction mixtures containing S-adenosylmethionine and three other ones without the addition of the methyl donor were incubated for three different periods, usually 5, 10 and $15 \mathrm{~min}$, because during this incubation time histamine was metabolized with a constant reaction velocity (see Results). The disappearance of histamine due to histamine methyltransferase was determined from the differences between the histamine concentration of the three incubation mixtures with and without the methyl donor. The initial velocity of reaction was calculated as the average from these three values. The activity of histamine methyltransferase was expressed as pmoles of histamine metabolized per min and mg protein.

\section{Results}

\section{Determination of Histamine and Histamine Methyltransferase in the Gastric Mucosa}

Inhibition of Diamine Oxidase and $N A D(P)$-Glycohydrolase. In mammalian tissues histamine is metabolized not only by histamine methyltransferase, but also by diamine oxidase, NAD(P)-glycohydro- 
lase, histamine acetylase and histamine transaminase (for review see Lorenz and Werle, 1969).

Among all of these enzymes only a very low activity of the diamine oxidase was demonstrated in the gastric mucosa and could be regularly measured only in the dog and cow (Kusche et al., 1969). Therefore, aminoguanidine, which is a strong inhibitor of this enzyme (Kusche et al., 1969), was added to the incubation mixtures. However, even in the presence of aminoguanidine a disappearance of histamine could be observed in those reaction mixtures, which did not contain any exogenous S-adenosylmethionine. This disappearance of histamine increased linearly with the incubation time, amounted to about $10 \%$ of that in the presence of S-adenosylmethionine $(34 \pm 8 \mathrm{pmoles} / \mathrm{min}$ and $\mathrm{mg}$ protein in the reaction mixtures with pig antral mucosa, $n=9$ ) and could be completely prevented by the addition of perchloric acid before the incubation. Therefore enzymatic reactions were assumed to account for this decrease of the histamine concentration in the incubation mixtures.

Studies with chlorpromazine, a potent inhibitor of histamine methyltransferase (Brown et al., 1959) and nicotinamide, an inhibitor of $N A D(P)$ glycohydrolase (Lorenz and Pfleger, 1968) showed that the disappearance of histamine in the absence of exogenous S-adenosylmethionine mostly seemed to be due to the action of the $\mathrm{NAD}(\mathrm{P})$-glycohydrolase. In about $80 \%$ of the mucosa samples ( $n$ about 500 ) $10^{-2} \mathrm{M}$ nicotinamide completely prevented the decrease of the histamine concentrations in the reaction mixtures. Histamine methyltransferase, which could use endogenous S-adenosylmethionine as methyl donor, was probably not involved under these conditions, since $5 \times 10^{-4} \mathrm{M}$ chlorpromazine in the reaction mixtures failed to inhibit the loss of histamine. In about $20 \%$ of the incubations further enzymes, like histamine acetylase and histamine transaminase, might be partially responsible for the disappearance of histamine. Nothing is known about their occurrence in the gastric mucosa or about inhibitors of these enzymes. Therefore it seemed necessary for the quantitative determination of the activity of histamine methyltransferase (1) to add nicotinamide to the incubation mixtures and (2) to incubate at least three reaction mixtures with and without the addition of S-adenosylmethionine. No inhibition of the histamine methyltransferase could be found in the presence of $1 \times 10^{-4} \mathrm{M}$ aminoguanidine and $1 \times 10^{-2} \mathrm{M}$ nicotinamide.

Reaction Kinetics. In the presence of S-adenosylmethionine histamine was metabolized in the incubation mixtures with crude extracts of guinea-pig brain with a constant reaction velocity up to $30-50 \mathrm{~min}$ (cf. Brown et al., 1959), with gastric mucosa of man up to $15-20 \mathrm{~min}$, with that of the dog up to $20-30 \mathrm{~min}$, with that of the pig up to 15 to $20 \mathrm{~min}$ and with that of the cow only up to $10-15 \mathrm{~min}$. However, since 
this time also showed some variations from one experiment to another, it proved necessary to follow the reaction kinetics in each determination of the activity of histamine methyltransferase. The decrease of the reaction velocity was not due to the consumption of S-adenosylmethionine or histamine because it could not be prevented by a second addition of one or both of these substances, when the initial velocity had decreased.

Histamine Concentration in the Incubation Mixtures. The histamine concentrations used by other authors for the determination of the enzyme were far below substrate saturation, e.g. $1.35 \times 10^{-5} \mathrm{M}$ (Netter and Bodenschatz, 1967). In the gastric mucosa the concentrations of endogenous histamine were relatively high (see Table 2 ) and varied considerably from one experiment to another. Therefore in this case the addition of only small amounts of exogenous histamine seemed not suitable for the quantitative determination of histamine methyltransferase. We used histamine concentrations, which were in the range of substrate saturation $\left(0.8-2.0 \times 10^{-4} \mathrm{M}\right)$ (cf. Methods).

Modification of the Method for the Determination of Histamine. The fluorometric assay of histamine (Shore et al, 1959) was improved by

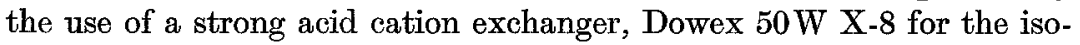
lation of histamine from the incubation mixtures. The recovery of histamine was $95-100 \%$ instead of $65-85 \%$ with the method of Shore et al. (1959). The procedure was less laborous and the specifity was higher, because all of the amino acids and amines which are known to interfere with the fluorometric assay of histamine (Shelley and Juhlin, 1966), were eliminated by the chromatography on Dowex $50 \mathrm{~W}$ X-8. This was proved by the addition of these substances in various concentration up to $1 \mathrm{mg} / \mathrm{ml}$ to $0.1 \mathrm{M}$ sodium phosphate buffer solutions (pH 6.5) containing histamine in various concentrations the lowest of which was $1 \mathrm{ng} / \mathrm{ml}$. The determination of $1 \mathrm{ng} / \mathrm{ml}$ histamine was not disturbed by $1 \mathrm{mg} / \mathrm{ml}$ spermine, spermidine, agmatine, arginine, histidine, citrulline and glutathion.

Furthermore, the substance isolated from the tissues by the ion exchange chromatography was identified as histamine by chemical and biological criteria: 1. After thinlayer chromatography when the plates were sprayed with $2 \mathrm{~N} \mathrm{NaOH}$ and o-phthaldialdehyde $(1 \% \mathrm{w} / \mathrm{v})$, only one fluorescent spot could be seen with $R_{\mathrm{f}}$-values of authentic histamine in all 8 solvent systems. 2. The activation and fluorescence spectra of the substance isolated from the tissues were identical with those of authentic histamine. 3. The histamine concentrations in the reaction mixtures, determined after the isolation procedure with the fluorometric assay and with the bio-assay on the isolated guinea-pig ileum and on the systemic blood pressure of the anesthetized cat, corresponded within the limits of only $\pm 5 \% .0 .1-0.5 \mu \mathrm{g}$ antazoline $/ \mathrm{ml}$ 
Tyrode solution in the bath completely abolished the contractions of the ileum which were induced by histamine and the substance isolated from the tissues.

\section{Distribution of Histamine Methyltransferase and Histamine in the Gastric Mucosa and Musculature}

In the gastric mucosa of man, dog, pig and cow, high activities of histamine methyltransferase could be demonstrated (Table 1). For comparison in the guinea-pig brain, which is known as one of the richest sources of this enzyme, $42-89$ pmoles histamine per min and $\mathrm{mg}$ protein were metabolized. The highest activity of the enzyme was found in the gastric mucosa of pigs, the lowest in that of cows.

Table 1. Histamine methyltransterase in the gastrie mucosa of man, dog, pig and cow

\begin{tabular}{lllllll}
\hline Species & \multicolumn{4}{l}{$\begin{array}{l}\text { Activity of histamine methyltransferase in pmoles histamine } \\
\text { inactivated, per min and mg protein after addition of S-adenosyl- } \\
\text { methionine }\end{array}$} \\
\cline { 2 - 7 } & $n$ & Fundus & $n$ & Corpus & $n$ & Antrum \\
\hline Man & $\mathbf{3}$ & $\mathbf{1 7 1} \pm 50$ & 4 & $\mathbf{6 1} \pm \mathbf{3 0}$ & $\mathbf{3}$ & $\mathbf{2 0 9} \pm \mathbf{5 1}$ \\
Dog & 2 & $\mathbf{1 2 2}$ & $\mathbf{3}$ & $\mathbf{7 3} \pm \mathbf{2 2}$ & $\mathbf{3}$ & $\mathbf{2 3 6} \pm \mathbf{1 3 9}$ \\
Pig & 4 & $\mathbf{2 4 2} \pm \mathbf{8 3}$ & $\mathbf{3}$ & $\mathbf{2 1 6} \pm \mathbf{1 5}$ & $\mathbf{7}$ & $\mathbf{4 6 5} \pm \mathbf{1 1 0}$ \\
Cow & $\mathbf{2}$ & $\mathbf{4 2}$ & $\mathbf{2}$ & $\mathbf{2 3}$ & $\mathbf{2}$ & $\mathbf{5 2}$
\end{tabular}

Mean values \pm S.D. From the cow only the rennet-bag was studied. $n$ number of men or animals tested. For incubation conditions see methods.

Table 2. Histamine content and activity of histamine methyltransferase in different parts of the gastric mucosa

\begin{tabular}{|c|c|c|c|c|c|c|c|c|}
\hline \multirow{3}{*}{$\begin{array}{l}\text { Part } \\
\text { of the } \\
\text { Gastric } \\
\text { mucosa }\end{array}$} & \multicolumn{8}{|c|}{$\begin{array}{l}\text { Histamine content (HA) } \\
\text { and activity of histamine methyltransferase (HMT) }\end{array}$} \\
\hline & \multicolumn{2}{|l|}{ Man } & \multicolumn{2}{|l|}{ Dog } & \multicolumn{2}{|l|}{ Pig } & \multicolumn{2}{|l|}{ Cow } \\
\hline & HA & HMT & HA & HMT & $\mathrm{HA}$ & HMT & $\mathrm{HA}$ & HMT \\
\hline Fundus & 22.5 & 228 & 81 & 122 & 92 & 310 & 53.5 & 35 \\
\hline Corpus 1 & 34.8 & 148 & 89 & 61 & 60 & 215 & 56.5 & 49 \\
\hline Corpus 2 & 16.5 & 105 & - & - & - & - & 32.2 & 45 \\
\hline Antrum 1 & 12.6 & 266 & 56 & 231 & 60 & 375 & 11.5 & 23 \\
\hline Antrum 2 & - & - & - & - & - & - & 26.8 & 52 \\
\hline
\end{tabular}

Histamine content in $\mu \mathrm{g}$ histamine hydrochloride/g wet weight. Activity of the enzyme in pmoles histamine inactivated/min and $\mathrm{mg}$ protein. Mean values from two determinations. Corpus of man and cow and antrum of cow were divided in two equal parts. Part 1 is the proximal one, part 2 is the distal one. Coefficient of correlation in the rennet-bag of cow: $r=0.43, p<0.5$. 
Histamine methyltransferase was not uniformly distributed in the stomach. Without any exception the highest activity of the enzyme in each of the four species was found in the antral mucosa, the lowest activity in the corpus. Contrary to the distribution of histamine and histidine decarboxylase (Lorenz et al., 1969, 1969a-c) there existed no relationship between the density of the parietal cells and the activity of the histamine methyltransferase. Furthermore, since no correlation could be shown between the histamine content and the activity of the enzyme in the gastric mucosa (Table 2), it seemed very probable, that histamine methyltransferase was not at all or not exclusively localized in mast cells as are histamine and histidine decarboxylase (Håkanson et al., 1969; Lorenz et al., 1969;1969a-c). In the musculature of the fundus and corpus of pigs and dogs histamine methyltransferase could not be detected.

\section{Purification and Stability of Histamine Methyltransferase}

Whereas a 6-8-fold purification of histamine methyltransferase from guinea-pig brain was achieved by fractional precipitation with ammonium sulfate, only a 2-3-fold purification of the enzyme from pig antral mucosa was obtained with the same procedure. Ultracentrifugation enhanced the specific activity 2-fold, so that the whole purification was 6-fold. No loss of total activity was found.

At $48^{\circ} \mathrm{C}$ in $0.05 \mathrm{M}$ sodium phosphate buffer $\mathrm{pH} 7.4$ the specific activity of histamine methyltransferase remained constant for $5 \mathrm{~min}$ and then decreased within $15 \mathrm{~min}$ to $50 \%$. This is contrary to the results of Lindahl (1960) who used crude extracts from pig liver. Temperatures from $50-70^{\circ} \mathrm{C}$ inactivated the enzyme from pig antral mucosa within $10 \mathrm{~min}$ almost completely. Thus this enzyme seemed to be rather sensitive to heat. On the other hand, the enzyme lost practically no activity at $-20^{\circ} \mathrm{C}$ during one week in crude extracts, and after purification and lyophilisation it remained stable for several weeks. Since after ultracentrifugation at $100000 \times \mathrm{g}$ for $1 \mathrm{~h}$ the whole activity was found in the supernatant and no activity in the sediment, the histamine methyltransferase of pig antral mucosa seemed to be a soluble and probably cytoplasmatic enzyme.

\section{Enzymic Properties of Histamine Methyltransferase of Pig Antral Mucosa}

The pH-optimum of histamine methyltransferase of pig antral mucosa was found to be at $\mathrm{pH} 7.4$ (Fig.1). The $\mathrm{pH}$-range of the optimal activity of the enzyme was relatively small. The Michaelis constants for 


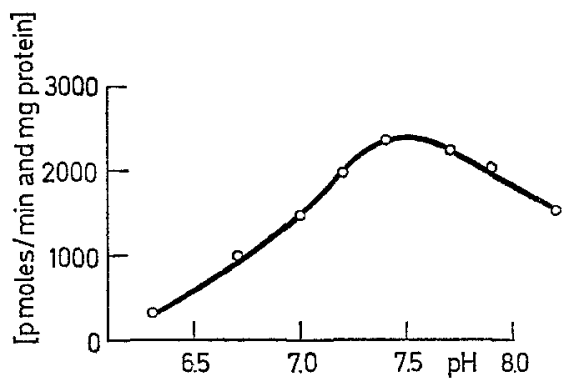

Fig. 1. pH-dependence of the activity of histamine methyltransferase from pig antral mucosa. Mean values from two determinations. $2 \mathrm{mg}$ protein/incubation mixture. For further conditions see Methods
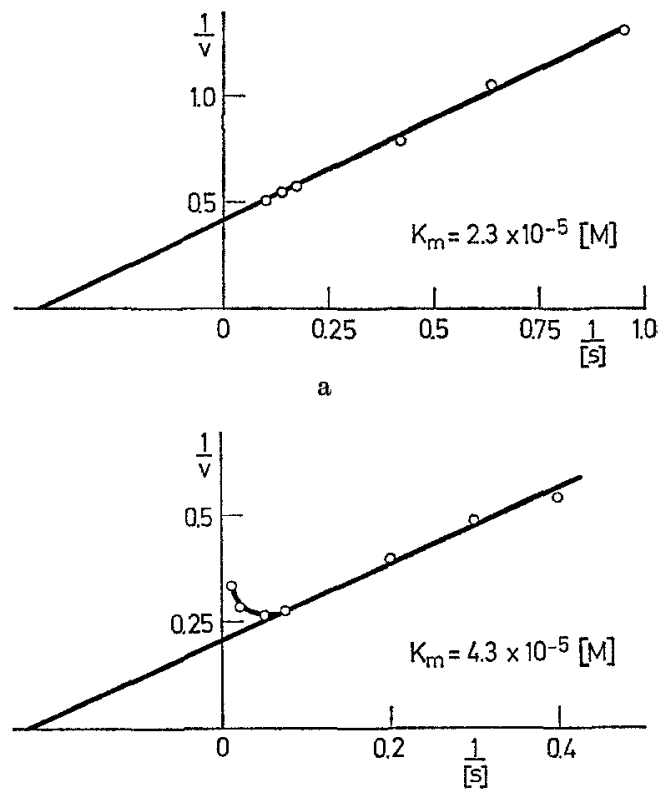

b

Fig. $2 \mathrm{a}$ and $\mathrm{b}$. Michaelis constants of histamine methyltransferase from pig antral mucosa (according to Lineweaver and Burk [19]). Mean values from four determinations. $2 \mathrm{mg}$ protein/incubation mixture, $\mathrm{pH} \mathrm{7.4,v} \mathrm{nmoles/min,}[S] a \times 10^{-5}[\mathrm{M}]$. a $K_{m}$ for histamine as substrate, concentration of S-adenosylmethionine $2.5 \times 10^{-4} \mathrm{M}$; b $K_{m}$ for S-adenosylmethionine as substrate, concentration of histamine $1.0 \times 10^{-4} \mathrm{M}$ For further conditions see Methods

histamine and S-adenosylmethionine were $2.3 \times 10^{-5} \mathrm{M}$ and $4.3 \times 10^{-5} \mathrm{M}$ (Fig. $2 \mathrm{a}$ and b). Concentrations of S-adenosylmethionine higher than $2.5 \times 10^{-4} \mathrm{M}$ inhibited the enzyme (Fig. $2 \mathrm{~b}$ ). 


\section{Diseussion}

Histamine in the gastric mucosa was thought to be "in a preferred position to histamine brought to or liberated in the mucosa of other portions of the gastro-intestinal tract. It will not be destroyed by diamine oxidase in the gastric mucosa, a most propitious and economical circum-

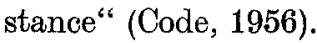

Indeed, no activity or a very low activity of diamine oxidase was found in the gastric mucosa of man and other mammals (Best and McHenry, 1930; Werle, 1940; Rose et al., 1940; Dworetzky and Code, 1951; Haeger and Kahlson, 1952; Waton, 1956; Kobayashi and Ivy, 1958, 1959; Kusche et al., 1969; Kim et al., 1969).

However, the conclusion drawn from this fact seems no longer acceptable, since histamine methyltransferase with high activity was shown to occur in the gastric mucosa of numerous species, with the only exception of the rat (Brown et al., 1959; Lindberg et al., 1963; Kim et al., 1969 and this paper). Furthermore, after injection of ${ }^{14} \mathrm{C}$-histamine relatively large amounts of ${ }^{14} \mathrm{C}-1,4$-methylhistamine and ${ }^{14} \mathrm{C}-1,4$-methylimidazole acetic acid were found in the gastric mucosa of dogs (Dombro et al., 1969) and relatively much endogenous 1,4-methylhistamine was detected in the stomach of the cat (White, 1966). Therefore histamine methyltransferase is very probably the enzyme which not only in vitro, but also in vivo inactivates histamine in the gastric mucosa.

Our results according to which this enzyme shows a high activity in the mucosa of fundus and corpus, are in agreement with the hypothesis that histamine is a physiological chemostimulator of gastric secretion. Surprisingly, the highest activity of histamine methyltransferase was found in the antrum of man, dog (see also Kim et al., 1969), pig and cow, but not in cat and different rodents. In all rodents studied the region containing the highest density of parietal cells was also the richest source of the enzyme (Kim et al., 1969). Lorenz et al. (1969c) pointed out that probably histamine does not only stimulate exocrine glands, but also has some other physiological functions in the digestive tract. Since relatively high concentrations of histamine (Lorenz and Pfleger, 1968; Lorenz, 1969; Lorenz et al., $1969 \mathrm{~b}, \mathrm{c}$ ) and histidine decarboxylase (Lorenz et al., 1969, 1969a) were found in the antrum of man and many animals, histamine could be involved in the release of gastrin, which should be studied with the radioimmuno-assay of this hormone. There were findings that histamine stimulated the release of peptide hormones in the hypophysis (Harris et al., 1952) and in the pancreatic islets (Vance and Bragg, 1969).

The properties of histamine methyltransferase from pig antral mucosa partially agree with those of preparations from other organs. The $K_{m}$ 
with histamine as substrate of the enzyme from guinea-pig brain was $3.5 \times 10^{-5} \mathrm{M}$ (Brown et al., 1959), from rat kidney $2.3 \times 10^{-5} \mathrm{M}$ (Netter and Bodenschatz, 1967) and from pig antrum $2.3 \times 10^{-5} \mathrm{M}$ (this paper), but the enzyme from pig liver showed a $K_{m}$ of $1.0 \times 10^{-4} \mathrm{M}$ (Lindahl, 1960). The $K_{m}$ for S-adenosylmethionine was $3.8 \times 10^{-4} \mathrm{M}$ with the enzyme from guinea-pig brain (Brown et al., 1959), but $4.3 \times 10^{-5} \mathrm{M}$ with the histamine methyltransferase from pig antrum and about $10^{-4} \mathrm{M}$ with the enzyme from pig liver (Lindahl, 1960). With enzyme preparations from guinea-pig brain the optimal $\mathrm{pH}$ for histamine methylation was 7.2-7.4 (Brown et al., 1959), with those from pig antrum 7.4, but with preparations from pig liver 10.0 (Lindahl, 1960). Therefore, the histamine methyltransferase of guinea-pig brain and pig antral mucosa, which behave similar at the precipitation by ammonium sulfate, seem to be rather similar enzymes, whereas the histamine methyltransferase of pig liver could be distinguished from them, especially by the pH-optimum.

We thank the Deutsche Forschungsgemeinschaft for a grant (Sonderforschungsbereich 37).

\section{References}

Axelrod, J., MacLean, P. D., Albers, R. W., Weissbach, W.: Regional distribution of methyltransferase enzymes in the nervous system and glandular tissue. p. 307. In: Regional neurochemistry, S. S. Kety and J. Elkes (eds.). Oxford: Pergamon Press 1961.

Best, C. H., McHenry, E. W.: The inactivation of histamine. J. Physiol. (Lond.) $70,349(1930)$.

Brown, D. D., Tomehick, R., Axelrod, J.: The distribution and properties of a histamine-methylating enzyme. J. Biol. Chem. 234, 2948 (1959).

Burkhalter, A.: Histamine formation by the fetal rat liver. Biochem. Pharmacol. 11, 315 (1962).

Code, C. F.: Histamine and gastric secretion. In: Ciba found. symp. on histamine, p. 189. G. E. W. Wolstenholme and C. M. O'Connor (eds.). London: J. \& A. Churchill 1956.

- Histamine and gastric secretion: A later look 1955-1965. Fed. Proc. 25, 1311 (1966).

Dombro, R., Huang, MI., Dittbrenner, M., Ragins, H.: Metabolio pathway of histamine in canine gastric mucosa in relation to acid secretion. Amer. J. Physiol. 216, 988 (1969).

Dworetzky, M., Code, C. F.: Passage of histamine across the wall of bowel. Amer. J. Physiol. 166, 462 (1951).

Håkanson, R., Lilja, B., Owman, Ch.: Cellular localization of histamine and monoamines in the gastric mucosa of man. Histochemie 18, 74 (1969).

Haeger, K., Kahlson, G.: Distribution of histamine and histaminase in the gastrointestinal mucosa of fed and starved cats. Acta physiol. scand. 25, 230 (1952).

Harris, G. W., Jacobsohn, D., Kablson, G.: The occurrence of histamine in cerebral regions related to the hypophysis. Ciba found. Coll. on Endocr. 4, 186 (1952). 
Kim, K. S., Backus, B., Harris, H., Rourke, P.: Distribution of diamine oxidase and imidazole-N-methyltransferase along the gastrointestinal tract. Comp. Biochem. Physiol. 31, 137 (1969).

Kobayashi, Y., Ivy, A. C.: Histamine metabolizing activity of dog's stomach and intestine. Amer. J. Physiol. 195, 525 (1958).

- - Histamine metabolizing activity of the stomach and intestine of the rat. Amer. J. Physiol. 196835 (1959).

Kusche J., Lorenz, W., Hahn, H., Werle, E.: Occurrence and properties of diamine oxidases in salivary glands and gastric mucosa of man and other mammals. Naunyn-Schmiedebergs Arch. Pharmak. 264, 265 (1969).

Lindahl, K. M.: The histamine methylating enzyme system in liver. Acta physiol. scand. 49, 114 (1960).

Lindberg, S., Lindell, S. E., Westling, H.: Formation and inactivation of histamine by human fetal tissues in vitro. Acta obstet. gynec, scand. 42, 49 (1963).

Lineweaver, H., Burk, D.: J. Amer. Chem. Soc. 56, 658 (1934).

Lorenz, W.: Lokalisation, Stoffwechsel und Frage einer physiologischen Funktion von Histamin in Speicheldrüsen, Schilddrüse und Magen. Thesis, University of Munich 1969.

- Halbach, St., Feifel, G., Haendle, H., Werle, E.: Determination, localization and properties of the specific histidine decarboxylases in the gastric mucosa of man and other mammals. Naunyn-Schmiedebergs Arch. Pharmak. 264, 273 (1969a).

- - Gerant, M., Werle, E.: Specific histidine decarboxylases in the gastric mucosa of man and, other mammals. Biochem. Pharmacol. 18, 2625 (1969).

- Pfleger, K. : Stoffwechsel und, physiologische Funktion von Histamin im Magen. Klin. Wschr. 46, 57 (1968).

- Schauer, A., Heitland, St., Calvoer, R., Werle, E.: Biochemical and histochemical studies on the distribution of histamine in the digestive tract of man, dog, and other mammals. Naunyn-Schmiedebergs Arch. Pharmak, 265, 81 $(1969 \mathrm{c})$.

- - Matekja, E., Werle, E.: Biochemical and histochemical studies on histamine in the digestive tract: distribution in different chordates and cellular stores in the dog. Naunyn-Schmiedebergs Arch. Pharmak. 264, 274 (1969 b).

- Werle, E.: Metabolic pathways of histamine and histidine decarboxylases. In: Intern. Encyclopedia of Pharmacology and Therapeutics Oxford: Pergamon Press 1969 (in press).

Netter, K. J., Bodenschatz, K.: Inhibition of histamine-N-methylation by some antihistaminics. Biochem. Pharmacol. 16, 1627 (1967).

Rose, B., Karady, S., Browne, J. S. L.: Histaminase content of tissues. Amer. J. Physiol. 129, 219 (1940).

Schayer, R. W.: The metabolism of histamine in various species. Brit. J. Pharmacol. 11, $472(1956)$.

- Cooper, J. A. D.: Metabolism of ${ }^{14} \mathrm{C}-$ histamine in man. J. appl. Physiol. 9, 481. (1956a).

Shelley, W. B., Juhlin, L.: Histamine chromatography and electrophoresis. The o-phthaldialdehyde fluorogram. J. Chromatogr. 22, 130 (1966).

Shore, P. A., Burkhalter, A., Cohn, V. H., Jr.: A method for the fluorometric assay of histamine in tissues. J. Pharmacol. exp. Ther. 127, 182 (1959).

Snedecor G. W., Cochran, W. G.: Statistical methods, p. 62. Ames, Iowa: Iowa State University Press 1967.

Thunberg, R.: Localization of cells containing and forming histamine in the gastric mucosa of the rat. Exp. Cell. Res. 47, 108 (1967). 
Vance, J. W., Bragg, S. C.: Insulin release in response to microvasoactive substances. Diabetes 18, Suppl. 1, 326 (1969).

Warburg, O., Christian, W.: Biochem. Z. 287, 291 (1936).

Waton, N. G.: Studies on mammalian histidine decarboxylase. Brit. J. Pharmacol. $11,119(1956)$.

Weichselbaum, T. E.: Protein determination by the biuret method. Amer. J. clin. Path. 10, 40 (1946).

Werle, E.: Zur Kenntnis der Histidindecarboxylase und Histaminase. Biochem. Z. 304, 201 (1940).

White, T.: Histamine and methylhistamine in cat brain and other tissues. Brit. J. Pharmacol. 26, 494 (1966).

Priv.-Dozent Dr. W. Lorenz

Institut für Klinische Chemie und Klinische Biochemie der Universität

D-8000 München 15, Nußbaumstr. 20 